\title{
PROTOTYPE APLIKASI PENGELOLAAN KEGIATAN PRAKERIN (PRAKTEK KERJA INDUSTRI) DAN PKL (PRAKTEK KERJA LAPANGAN) BERBASIS WEB
}

\author{
Gita Ayu Syafarina ${ }^{1}$, Rusdina ${ }^{2)}$ \\ ${ }^{1)}$ Fakultas Teknologi Informasi , Universitas Islam Kalimantan MAB Banjarmasin \\ Email : gitaayusyafarina@gmail.com \\ ${ }^{2)}$ Fakultas Teknologi Informasi , Universitas Islam Kalimantan MAB Banjarmasin \\ Email : russidina@gmail.com
}

\begin{abstract}
Abstrak
Setiap Sekolah Menengah Kejuruan (SMK) baik yang Negeri ataupun Swasta selalu mengirimkan siswa nya untuk PRAKERIN (Praktek Kerja Industri) Pada sebuah perusahaan atau pun perorangan seperti toko, swalayan dan sebagainya. Untuk menunjang kegiatan tersebut maka kami membuat Aplikasi/perangkat lunak berbasis web yang bisa memudahkan operator/bagian HRD perusahaan untuk mendata dan mengelola para siswa yang akan dan sedang melakukan kegiatan PRAKERIN dan PKL. Jika selama ini untuk data siswa masih didata secara semi komputerisasi memakai micrososft Office yaitu Excel saja. Maka kami merancang sebuah aplikasi berbasis web yang bisa diakses secara online maupun offline dengan menggunakan pemrograman berbasis PHP . Dengan adanya aplikasi Pengelolaan Kegiatan Prakerin (Praktek Kerja Industri) dan PKL (Praktek Kerja Lapangan) ini, maka pengelolaan data akan lebih mudah dan efesien.
\end{abstract}

Kata Kunci : Excel, PHP,PRAKERIN,PKL, Web

\section{PENDAHULUAN}

PRAKERIN (Praktek Kerja Industri) adalah sebuah kegiatan dalam pendidikan, pelatihan serta pembelajaran yang biasanya dilaksanakan pada Dunia Usaha dan Dunia Industri didalam upaya untuk meningkatkan mutu siswa dan siswi Sekolah Menengah Kejuruan (SMK) dengan berbagai kompetensi /kemampuan siswa yang sesuai bidang nya dan juga untuk menambah bekal pada masa mendatang untuk memasuki dunia kerja yng semakin banyak dan ketat dalam persaingan seperti sekarang ini. Dapat diartikan sebagai suatu program yang merupakan sarana pelatihan untuk menerapkan berbagai pengetahuan, sikap dan keterampilan dalam rangka pembentukan awal sarjana komputer yang profesional. Dengan demikian PRAKERIN adalah suatu program aplikasi yang terpadu dari seluruh pengalaman belajar sebelumnya ke dalam program pelatihan berupa kinerja dalam semua hal yang berhubungan dengan dunia kerja yang sudah ada. Kegiatan. Selama ini untuk data data siswa masih didata secara semi komputerisasi yaitu memakai micrososft Office yaitu Excel saja. Walaupun sudah ada aplikasi serupa yaitu aplikasi magang dan sebagainya, kami akan merancang sebuah aplikasi berbasis web yang bisa diakses secara online dengan menggunakan pemrograman berbasis web yaitu PHP . Dengan adanya aplikasi Perancangan Pengelolaan Kegiatan Prakerin (Praktek Kerja Industri) Berbasis Web ini data-data pengelolaan siswa PRAKERIN akan lebih mudah dicari dan di rangkumkan jika diperlukan.

Rumusan masalah yang akan dibahas di penelitian ini adalah bagaimana sistem Perancangan Aplikasi Pengelolaan Kegiatan Prakerin (Praktek Kerja Industri) Berbasis Web ini dapat membantu menata dan mengelola siswa yang akan melakukan kegiatan PRAKERIN dengan menggunakan bahasa pemrograman PHP dengan Sublime Text sebagai editor Text nya. Sedangkan Tujuan dari penelitian ini adalah membuat sebuah Perancangan Aplikasi Pengelolaan Kegiatan PRAKERIN (Praktek Kerja Industri) Berbasis Web. Adapun Manfaat yang 
diharapkan dari penelitian ini yaitu Adapun manfaat dari penelitian ini adalah

1. Mempermudah orang yang bersangkutan dalam penginputan data.

2. Mencegah data yang sama terinput lebih dari satu kali.

3. Mencegah data terhapus tidak sengaja.

4. Membantu orang yang berwenang dalam mengelola data.

5. Mencegah orang yang tidak memeiliki izin untuk memodifikasi data.

\section{TINJAUAN PUSTAKA}

Sublime Text merupakan editor kode untuk sumber lintas platform yang bersifat eksklusif untuk antarmuka pemrograman aplikasi Python (API) .Secara native mendukung begitu banyak bahasa pemrograman serta mark up, fungsi dapat ditambahkan oleh User dengan plugin, dibuat oleh sebuah komunitas dan dipelihara/maintenance di bawah lisensi perangkat lunak bebas (open).

Di bawah merupakan fitur dari Sublime Text :

- Navigasi lebih cepat ke file, simbol, dan garis atau Go to Anything

- Sublime menggunakan pencocokan yang adaptif untuk perintah cepat ke keyboard (Command palette) jadi bukan yang sembarangan atau

- Pengeditan secara simultan maksudnya secara bersamaan melakukan perubahan yang interaktif berupa sama ke area yang dipilih

- API plugin nya berbasis Python

- Preferensi spesial/khusus proyek

- Ekstensif customizability yaitu melalui file pengaturan JSON jadi termasuk pengaturan spesifik proyek dan platform-spesifik lainnya.

- Cross-platform/lintas platform yaitu bisa di Linux , macOS ,Windows) dan Plugin Pendukung lainnya.

- Compatible dengan banyaknya grammar bahasa dari TextMate.

Sublime Text 2.0.2 adalah yang pernah dirilis pada 8 Juli 2013. Versi pertama dari software dipromosikan oleh Skinner di Web resmi Sublime termasuk dukungan tampilan Retina dan fungsi "Quick Skip Next".

Sedangkan PHP (PHP:Hypertext Preprocessor) atau yang biasa di sebut bahasa pemrograman server side karena PHP (PHP:Hypertext Preprocessor) diproses pada sebuah komputer server.Hal ini sangat berbeda jika dibandingkan dengan bahasa pemrograman lainnya yaitu client-side seperti JavaScript yang diprosesnya pada web browser atau client.

\section{METODE PENELITIAN}

Dalam penelitian ini, yang diterapkan adalah Metode penelitian Case study (studi kasus) . Menurut Zainal A Hasibuan (2007) Studi kasus adalah merupakan penelitian yang memusatkan perhatian pada suatu kasus tertentu dengan menggunakan objek berupa individu ataupun kelompok sebagai bahan studinya. Penggunaan penelitian ini biasanya difokuskan untuk menggali serta mengumpulkan data yang lebih dalam terhadap obyek /kelompok yang sudah diteliti untuk dapat menjawab permasalahan-permasalahan yang sedang terjadi.Jadi bisa dikatakan bahwa penelitian ini juga bersifat deskriptif dan eksploratif.

Berdasarkan analisa dan masalah yang dipaparkan dilatar belakang, maka Kami merancang suatu program aplikasi untuk memecahkan masalah tersebut sebagai berikut :

Merancang program yang akan mempermudah orang yang bersangkutan menginput data, merancang program yang akan mempermudah pencarian data siswa prakerin,merancang program yang akan membantu memvalidasi data yang masuk,Merancang program yang akan ada menu-menu yang berkaitan dengan kegiatan prakerin dan PKL. 
Untuk alur atau flowchart sistem seperti di bawah ini :

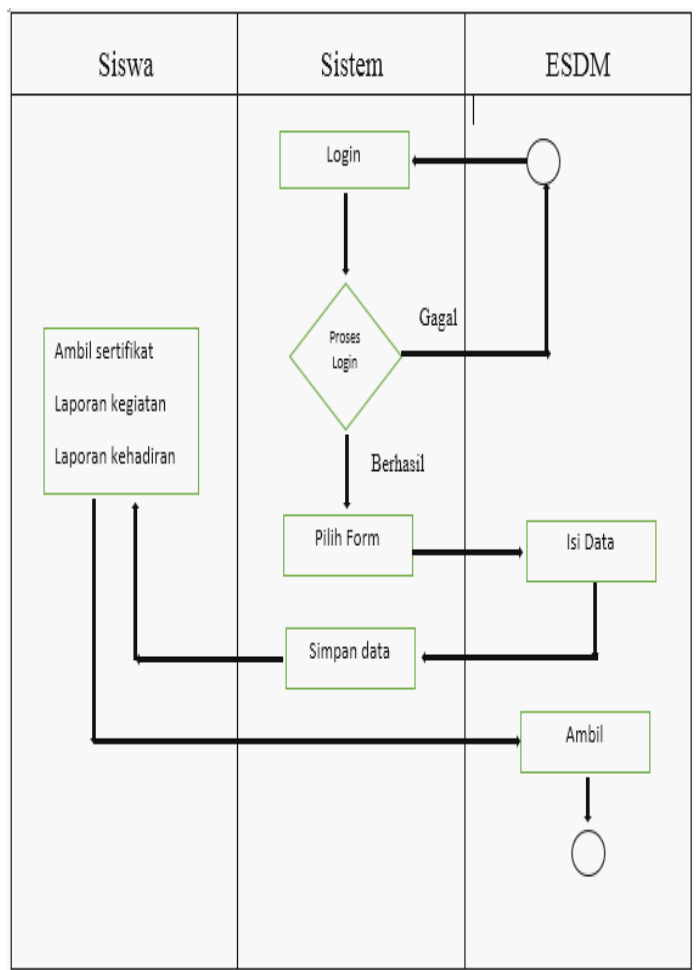

Gambar 1 FlowChart Sistem yang di bangun

flowchart sistem :

Berikut adalah penjelasan tentang

1. Admin login terlebih dahulu kedalam sistem.

2. Apabila gagal, maka akan dikembalikan kehalaman login.

3. Admin menginputkan data siswa magang yang telah diserahkan siswa sebelumnya kepada admin.

4. Setelah diinput, siswa bisa meminta laporan kegiatan kepada admin

Sequence diagram yaitu suatu diagram yang menggambarkan alur dan interaksi antar obyek serta mengindikasikan komunikasi diantara obyek tersebut. Sequence juga menunjukkan serangkaian pesan yang dipertukarkan antar obyek yang melakukan suatu tugas tertentu. Dalam penelitian ini, Sequence diagram sistemnya yaitu seperti berikut :

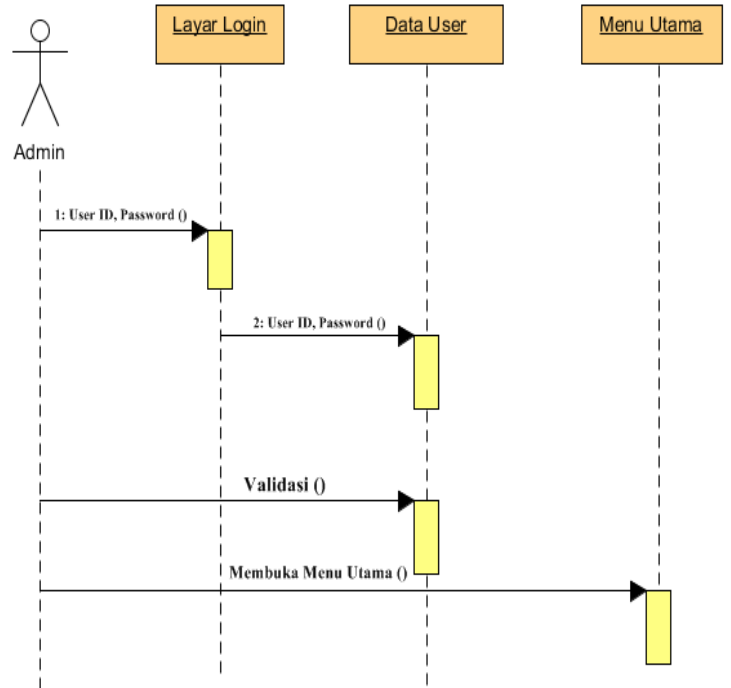

Gambar 2 Sequence Diagram pada sistem

ERD (Entity Relationship Diagram) adalah sebuah model untuk menyusun database (basis data) agar dapat menggambarkan data yang mempunyai relasi dengan database yang akan didesain. Berikut adalah ERD (Entity Relationship Diagram) Aplikasi yang dibuat :

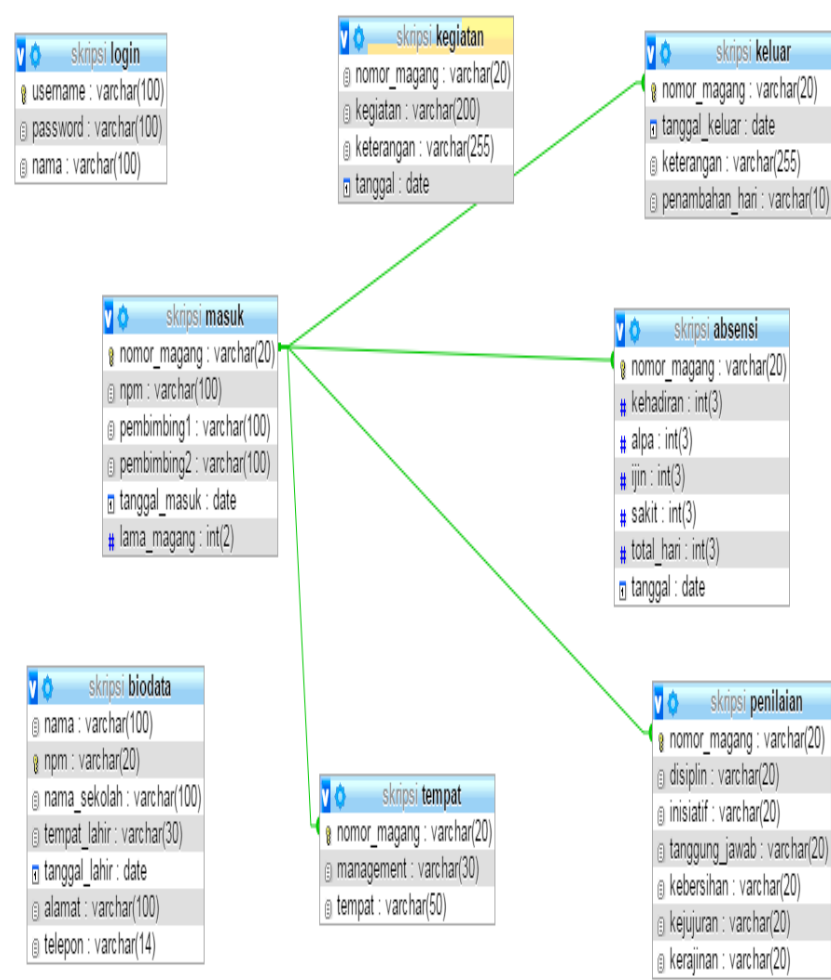

Gambar 3 Entity Relationship Diagram 


\section{HASIL IMPLEMENTASI PENELITIAN} buat :

Untuk Hasil Tampilan Aplikasi yang

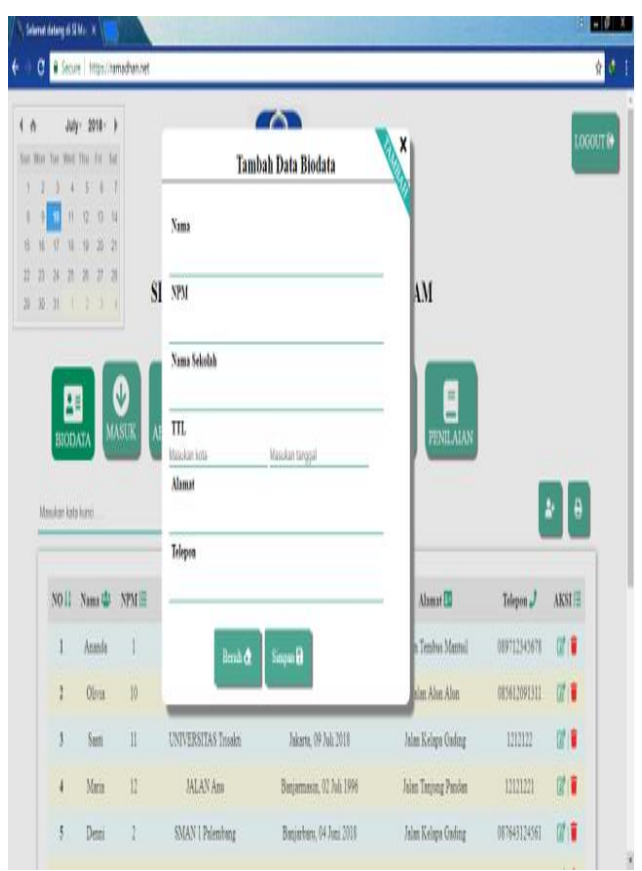

Gambar 4 Form Input biodata peserta Prakerin/PKL

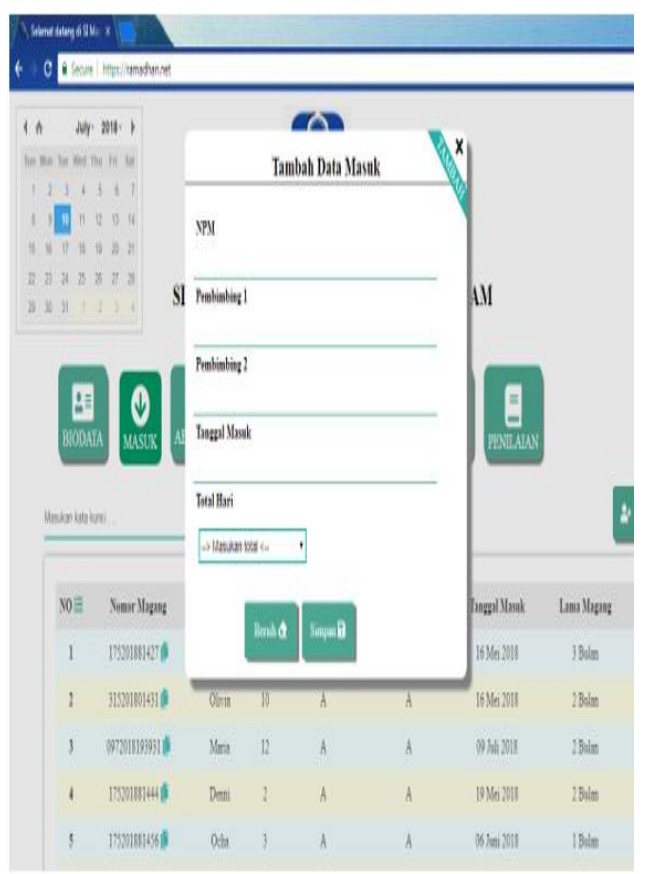

Gambar 5 Form Input masuk seperti No.induk siswa dan Nama Pembimbing
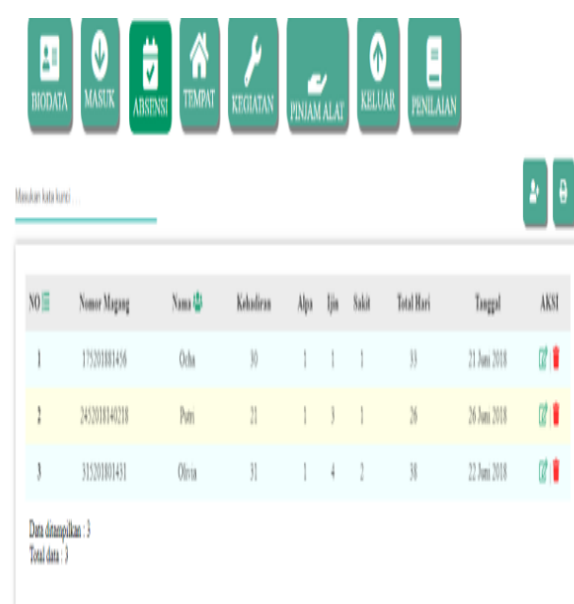

Gambar 6 Absensi Peserta Prakerin/PKL

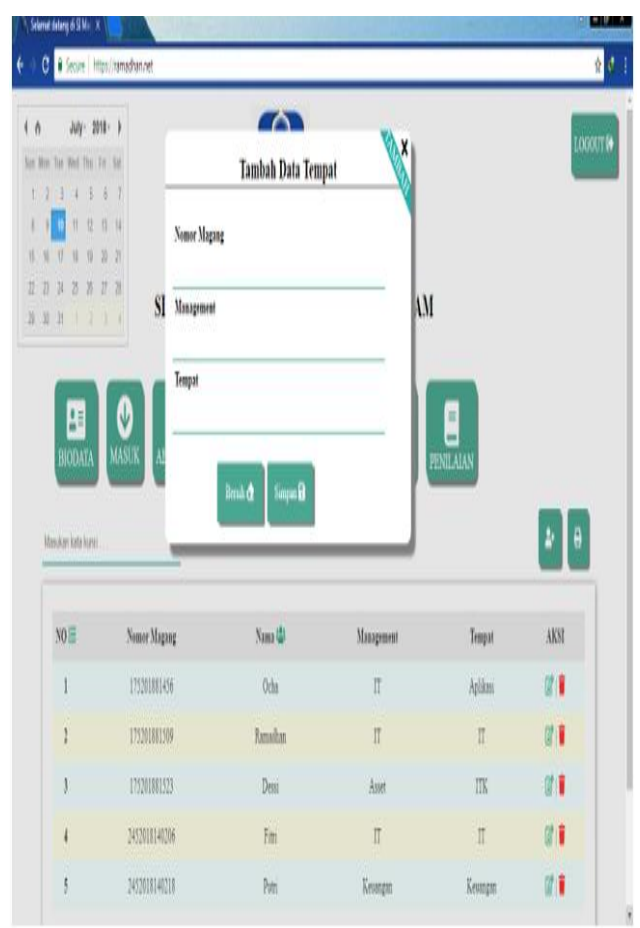

Gambar 7 Form Data Tempat

Selanjutnya adalah tahap Pengujian pada sistem . Tahap pengujian dilakukan sebagai proses untuk memeriksa apakah aplikasi yang dihasilkan berjalan sesuai dengan standar / tujuan . Metode pengujian yaitu menggunakan cara atau teknik untuk menguji aplikasi, mempunyai mekanisme untuk menentukan data uji yang dapat mengetahui aplikasi secara lengkap/sampai selesai dan mempunyai kemungkinan tinggi untuk menetukan kesalahan/error yang ada pada aplikasi.

Dibawah adalah salah satu pengujian yang dilakukan pada penelitian ini, yaitu 
menggunakan metode pengujian Blackbox. Blackbox testing dilakukan jika sebuah sistem sudah selesai dibangun, maksudnya aplikasi yang sudah selesai dilakukan test satu persatu untuk mengetahui apakah setiap Form input maupun output tidak mengalami kegagalan sistem/ error. Berbeda dengan whitebox testing yang menguji setiap koding aplikasi yang dibuat yang artinya pengujian harus dilakukan oleh seorang programer murni, Blackbox testing bisa langsung oleh user atau pengguna tanpa harus mengerti koding sama sekali. Berikut adalah blackbox testing yang dilakukan dalam penelitian ini.

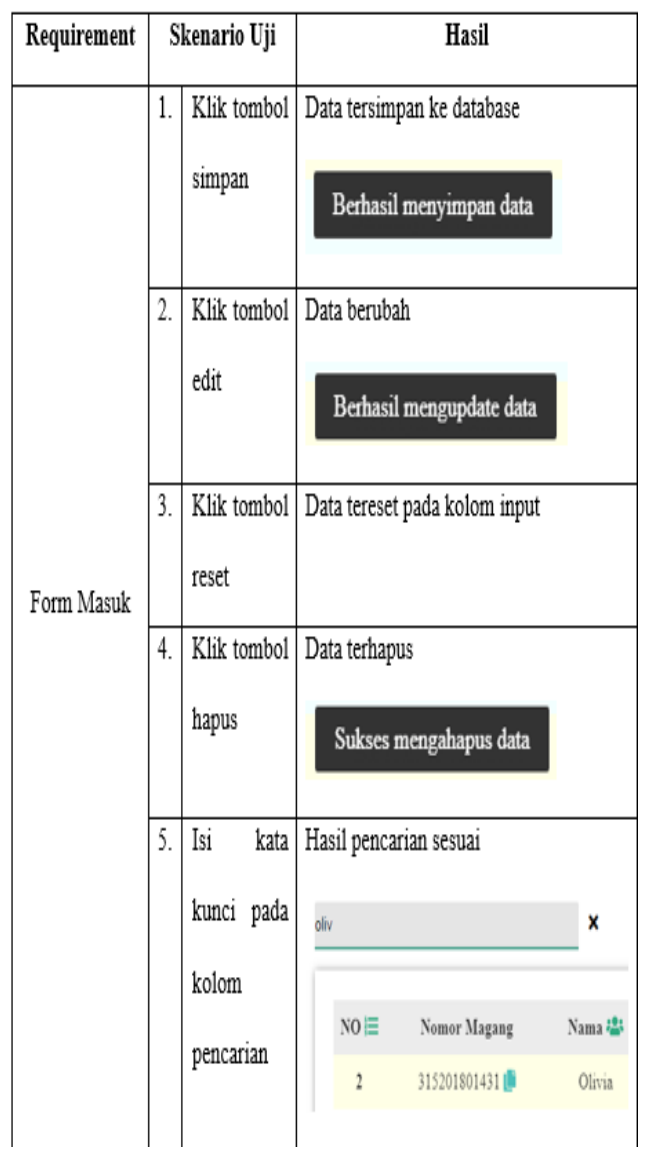

Gambar 8 Pengujian BlackBox form Masuk

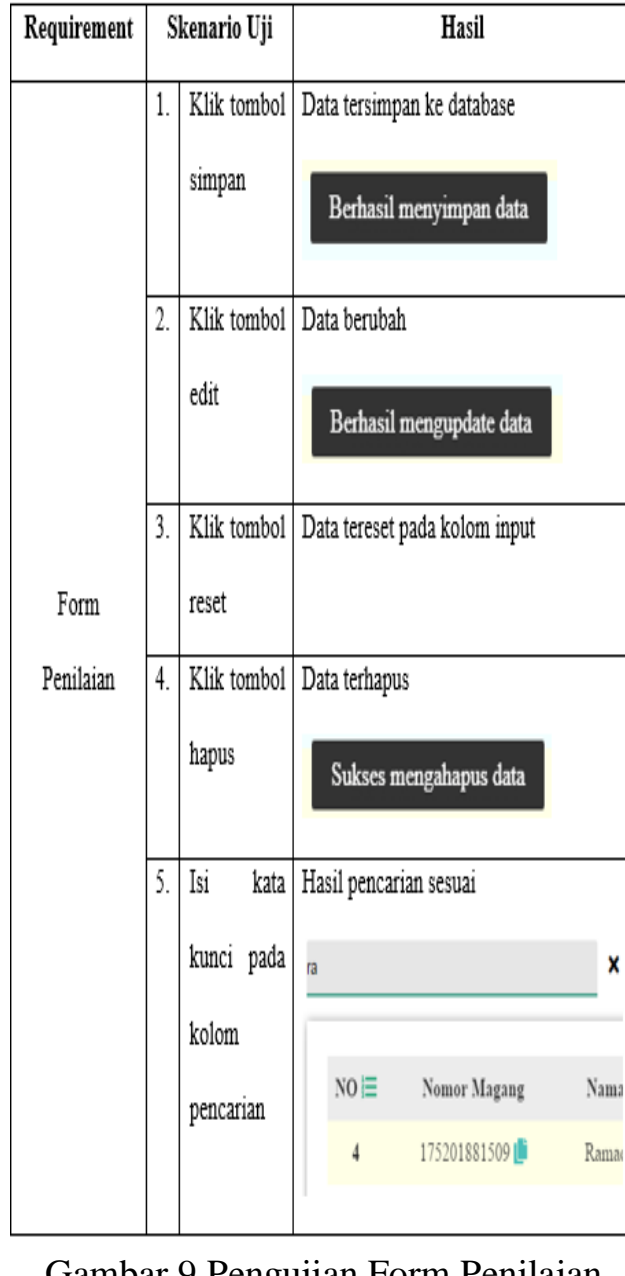

Gambar 9 Pengujian Form Penilaian

Setelah pengujian sudah dilakukan maka sistem sudah siap di implementasikan ke objek yaitu perusahaan yang menerima mahasiwa/ siswa Prakerin/ PKL karena aplikasi ini dapat menggantikan pekerjaan yang semi komputerisasi menjadi sistem otomatis yaitu menggunakan sistem yang lebih ringkas dan mudah.

\section{KESIMPULAN}

Kesimpulan yang dapat diambil dari penelitian ini yaitu Aplikasi ini dapat digunakan untuk membantu kinerja Perusahaan dalam mengolola data serta data pendukung lainnya dimana admin tersebut hanya menginputkan data saja dan proses Simpan dilakukan oleh komputer sehingga akan meminimalkan tingkat kekeliruan yang biasanya terjadi dalam sistem manual. 


\section{REFERENSI}

[1] Bhirawa, N. A. \& Sukardi, 2014. Pembuatan Website Portal Berita Desa Jetis Lor. IJNS-Indonesian Journal on Networking and Security.

[2] Suyanto, Asep Herman. 2007. Step by Step: Web Design Theory and Practices. Yogyakarta: Andi Offset.

[3] Hutahaean, J., 2014. Konsep Sistem Informasi. Yogyakarta: CV. Budi Utama.

[4] Rina Alfah, T. V. R., 2018. Sistem EPrescribing Dan BARCODE SYSTEM Untuk Resep Obat Di Rumah Sakit. Jurnal Teknologi Informasi Universitas Lambung Mangkurat (JTIULM), 03(Vol. 3 No. 2 (2018)), pp. 59-70.

[5] Agustina, D. 2016, November26. Apa Itu Aplikasi? Retrieved from jogjaweb.co.id:

https://jogjaweb.co.id/blog/apa-ituaplikasi

[6] Syamsu Rizal, E. R. A. I., 2013. Pengembangan Aplikasi Pencarian Lokasi Objek Wisata Terdekat Di Kabupaten Garut Berbasis Android. Sekolah Tinggi Teknologi Garut. 